\title{
Inhibitory effect of dihydromyricetin on the proliferation of JAR cells and its mechanism of action
}

\author{
YANZHEN ZUO ${ }^{1}$, YANJIE LU $^{2}$, QIAN XU ${ }^{3}$, DAYONG SUN ${ }^{4}$, XIUJUN LIANG ${ }^{3}$, XIAORU LI $^{5}$ and YUHONG $\mathrm{LI}^{2}$ \\ Departments of ${ }^{1}$ Pharmacology and ${ }^{2}$ Pathology; ${ }^{3}$ Research Laboratory, Chengde Medical University; \\ Departments of ${ }^{4}$ Tumor Radiation and Chemotherapy Center, and ${ }^{5}$ Gynaecology, Chengde Central Hospital, \\ Chengde, Hebei 067000, P.R. China
}

Received July 10, 2019; Accepted March 5, 2020

DOI: $10.3892 / \mathrm{ol} .2020 .11546$

\begin{abstract}
Dihydromyricetin (DMY) is a novel natural drug with antitumor activity against some cancer cells without obvious toxicity. Previously, its apoptotic effect on human choriocarcinoma was detected. The present study further investigated the therapeutic potential of DMY as a new drug for the treatment of choriocarcinoma, as well as its anti-proliferative effect and mechanism of action. The short-term proliferation of JAR cells was determined by MTT assay, whereas the effect of DMY on long-term cell proliferation was determined by colony forming assay. Flow cytometry was used to detect changes in the cell cycle. Furthermore, western blotting was used to detect the expression levels of proliferation-associated proteins such as cyclin A1, cyclin D1, SMAD3 and SMAD4. Reverse transcription-quantitative PCR (RT-qPCR) was used to quantify mRNA expression levels. The results indicated that DMY inhibited short and long-term proliferation of JAR cells in a concentration-dependent manner. Flow cytometry demonstrated $\mathrm{S} / \mathrm{G}_{2} / \mathrm{M}$ cell cycle arrest, and western blotting revealed the downregulation of SMAD3, SMAD4, cyclin A1 and cyclin D1 expression levels. The results of RT-qPCR and western blotting were consistent. Overall, the findings of the present study suggest that DMY inhibits the proliferation of human choriocarcinoma JAR cells, potentially through cell cycle arrest via the downregulation of cyclin A1, cyclin D1, SMAD3 and SMAD4 expression levels.
\end{abstract}

\section{Introduction}

Choriocarcinoma is the most aggressive type of trophoblastic neoplasia (1). It is prone to early distant metastases and has aggressive features, leading to a generally poor prognosis $(2,3)$.

Correspondence to: Professor Yuhong Li, Department of Pathology, Chengde Medical University, 28 Anyuan Street, Chengde, Hebei 067000, P.R. China

E-mail: youngcheer2003@foxmail.com

Key words: choriocarcinoma, proliferation, dihydromyricetin, JAR cells, cell cycle
With advancements in multidrug combination chemotherapy, the cure rate of choriocarcinoma has significantly improved (4). However, some patients still fail to respond to treatment due to the strong proliferative and invasive abilities of choriocarcinoma, as well as the severe toxic side effects of chemotherapy, and multidrug resistance to chemotherapy (5). Thus, it is important to inhibit the proliferation and invasion of choriocarcinoma cells, and to explore new anticancer drugs with low toxicity and high efficiency.

Dihydromyricetin (DMY) is a natural flavonoid isolated from Ampelopsis grossedentata, which reportedly has anti-inflammatory, antioxidative, anticancer, antimicrobial and immune-enhancing effects (6). DMY exerts a strong antitumor effect with low toxicity to normal cells (7-9). Its mechanism of action primarily involves the inhibition of proliferation, migration and invasion, as well as the induction of apoptosis (10-12). In a previous study, the effect of DMY-induced apoptosis on choriocarcinoma cells was studied (13). The present study aimed to explore the inhibitory effect of DMY on the proliferation of JAR cells and its associated mechanisms of action, in order to provide data to support the development of DMY as a novel therapy for choriocarcinoma.

Cell proliferation is closely associated with the cell cycle, which is an essential mechanism by which all living organisms grow and proliferate. The eukaryotic cell cycle usually comprises four phases. The cells grow continuously during interphase, which comprises three phases: $G_{1}, S$ And $G_{2}(14)$. The $G_{1}$ phase is the gap between the $M$ and $S$ phases, and it is an active period of metabolic activity, cell growth and repair. It is an important phase wherein the cells decide whether to enter the $S$ phase. The $S$ phase is flanked by the $G_{1}$ and $G_{2}$ phases, during which the cells continue to grow. During the $S$ phase, the cells undergo DNA replication. The $G_{2}$ phase is the gap between the $\mathrm{S}$ and $\mathrm{M}$ phases, and DNA synthesis occurs in anaphase, which is the preparatory phase of mitosis. During this period, DNA synthesis is terminated; furthermore, several RNAs and proteins. including tubulin and maturation promoters. are produced. At specific points in the $G_{2}$ phase, cells encounter different checkpoints at which the decision of proceeding to the next phase or pausing to allow more time for preparation is made. The $S, G_{1}$ and $G_{2}$ phases form part of the interphase, which is a markedly active period for proliferating cells. The $\mathrm{M}$ phase is the mitotic phase; during this phase, the 
nucleus divides via mitosis, which is followed by cytoplasmic division via cytokinesis (14). Cyclins are important proteins in the cell cycle control system. Detection of changes in the cell cycle and cyclins can further clarify the mechanisms underlying cell proliferation.

The transforming growth factor- $\beta$ (TGF- $\beta$ )/SMAD signaling pathway is also closely associated with cell proliferation. Previous studies have shown that this pathway can regulate the proliferation of choriocarcinoma cells $(15,16)$. However, the inhibitory effect of DMY on proliferation, in association with the TGF- $\beta$ /SMAD signaling pathway, needs further clarification.

\section{Materials and methods}

Reagents. The following commercial reagents were used: DMY (>99\% purity; Beijing Century Aoke Biotechnology Co., Ltd.), fetal bovine serum (Gibco; Thermo Fisher Scientific, Inc.), DMEM (Gibco; Thermo Fisher Scientific, Inc.), $0.25 \%$ trypsin with $0.02 \%$ EDTA (Gibco; Thermo Fisher Scientific, Inc.), MTT reagent (Gibco; Thermo Fisher Scientific, Inc.), antibodies against GAPDH (rabbit anti-human polyclonal; cat. no. E12-052; EnoGene Biotech Co., Ltd.), SMAD3 (rabbit anti-human monoclonal; cat. no. ab40854; Abcam), p-SMAD3 (rabbit anti-human monoclonal; cat.no. ab52903; Abcam), SMAD4 (rabbit anti-human monoclonal; cat. no. ab40759; Abcam), Cyclin A1 (rabbit anti-human polyclonal; cat. no. E1A5313; EnoGene Biotech Co., Ltd.) and Cyclin D1 (rabbit anti-human monoclonal; cat. no. ab134175; Abcam), and a secondary antibody (peroxidase-conjugated AffiniPure goat anti-rabbit IgG; cat. no. ab6721; Abcam).

Cell culture. The human JAR cell line (male fetus choriocarcinoma) was purchased from Guangzhou Jennio Biotech Co., Ltd. JAR cells were cultured in $10 \%$ DMEM at $37^{\circ} \mathrm{C}$ in the presence of $5 \% \mathrm{CO}_{2}$. Subsequently, the cells were subcultured with $0.25 \%$ trypsin and $0.02 \%$ EDTA until confluence reached $70-80 \%$.

MTT assay. MTT assays were performed as described previously (13). Cells were seeded in 96-well plates, cultured overnight until the cell confluence reached $30-40 \%$, and incubated for $48 \mathrm{~h}$ with various concentrations of DMY: 0, 20, $40,80,100,120,160,240$ and $320 \mathrm{mg} / \mathrm{l}(0,62,125,250,312$, 375, 500, 749 and $999 \mu \mathrm{M}$ ), in $200 \mu 110 \%$ DMEM per well. There were 6 wells for each group. MTT reagent was used to determine cell proliferation, and absorbance was determined using a microplate reader (Multiskan MK3; Thermo Fisher Scientific, Inc.) at a wavelength of $492 \mathrm{~nm}$. The experiment was repeated three times.

Live cell imaging. According to the MTT results, 0, 40, 60 and $100 \mathrm{mg} / \mathrm{l}(0,125,187$ and $312 \mu \mathrm{M})$ were selected as the appropriate concentrations to perform further experiments. Cell proliferation was observed under an inverted light microscope at x100 magnification (Olympus IX73; Olympus Corporation), and cell confluence was analyzed using the PAULA live cell imaging system (Leica Microsystems $\mathrm{GmbH})$.
Table I. Primer pairs used in quantitative PCR.

\begin{tabular}{ll}
\hline Gene & \multicolumn{1}{c}{ Sequence (5' to $\left.3^{\prime}\right)$} \\
\hline SMAD4 & F: gacagcagcagatggat \\
& R: caggagcaggatgattgg \\
SMAD3 & F: ccagggctttgaggctgtcta \\
& R: gcaaaggcccattcaggtg \\
Cyclin A1 & F: tgtcaccgttcctcettg \\
& R: gcatcttcacgctctattt \\
Cyclin D1 & F: gcgaggaacagaagtgcg \\
& R: tggagttgtcggtgtagatgc \\
GAPDH & F: gcaccgtcaaggctgagaac \\
& R: tggtgaagacgccagtgga
\end{tabular}

F, forward; R, reverse.

Colony forming assay. Cells were seeded in culture plates and allowed to adhere overnight. Once the confluence reached $30-40 \%$, the cells were incubated with different concentrations of DMY $(0,40,60$ and $100 \mathrm{mg} / \mathrm{l})$ in $10 \%$ DMEM at $37^{\circ} \mathrm{C}$ of $5 \% \mathrm{CO}_{2}$. Following a 48-h incubation, the cells were resuspended and subsequently replated at a density of 400 cells/well in 6-well plates. After a 12-day culture, the cells were stained with crystal violet for $30 \mathrm{~min}$ at room temperature, colonies were counted using ImageJ version 1.46 (National Institutes of Health), and images of cell morphology were captured using a camera (Nikon Corporation).

Cell cycle analysis. Cells were seeded in culture plates and allowed to adhere overnight. Once the cell confluence had reached $30-40 \%$, the cells were incubated with different concentrations of DMY $(0,40,60$ and $100 \mathrm{mg} / \mathrm{l})$. After a 48-h incubation period, the cell cycle was analyzed using flow cytometry. The cells were processed with the Cell Cycle kit [cat. no. CCS012; Multi Sciences (Lianke) Biotech Co., Ltd.], according to the manufacturer's instructions. The samples were analyzed using a FACSCalibur flow cytometer (Becton, Dickinson and Company).

Reverse transcription-quantitative PCR (RT-qPCR). Cells were incubated with different concentrations of DMY $(0$, 40, 60 and $100 \mathrm{mg} / \mathrm{l}$ ) for $48 \mathrm{~h}$. Total RNA was isolated using TRIzol $^{\circledR}$ reagent (Sigma-Aldrich; Merck KGaA), according to the manufacturer's instructions. cDNA synthesis was performed using the PrimeScript RT Reagent kit (cat. no. RR036A; Takara Biotechnology Co., Ltd.) according to the manufacturer's instructions. qPCR was performed using the SYBR Green qPCR Master mix (cat. no. RR820A; Takara Biotechnology Co., Ltd.), according to the manufacturer's instructions. PCR was performed under the following conditions: Denaturation at $95^{\circ} \mathrm{C}$ for $30 \mathrm{sec}$, followed by 40 cycles at $95^{\circ} \mathrm{C}$ for $5 \mathrm{sec}, 55^{\circ} \mathrm{C}$ for $30 \mathrm{sec}$ and $72^{\circ} \mathrm{C}$ for $30 \mathrm{sec}$, finally 1 cycle at $95^{\circ} \mathrm{C}$ for $60 \mathrm{sec}$, $55^{\circ} \mathrm{C}$ for $30 \mathrm{sec}$ and $95^{\circ} \mathrm{C}$ for $30 \mathrm{sec}$. Three repeated wells were set up of each sample. The expression intensity of each gene was normalized against the expression of GAPDH. Differential gene expression was calculated as the ratio of the expression levels of 
A

MTT assay

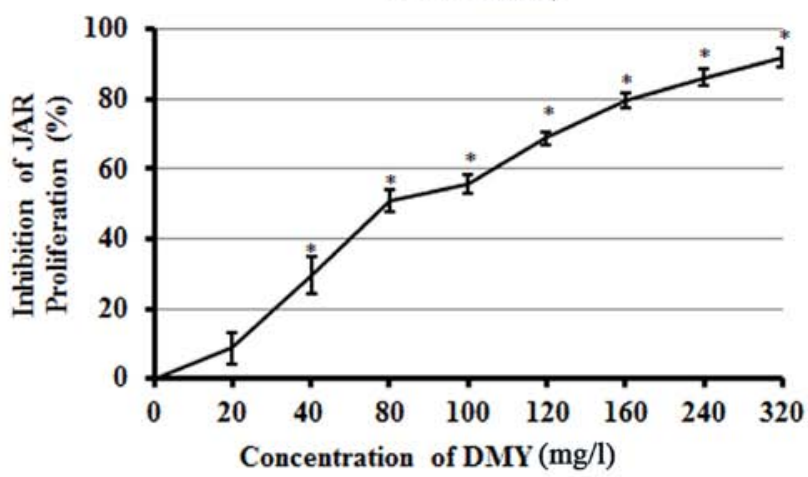

$\mathrm{B}$
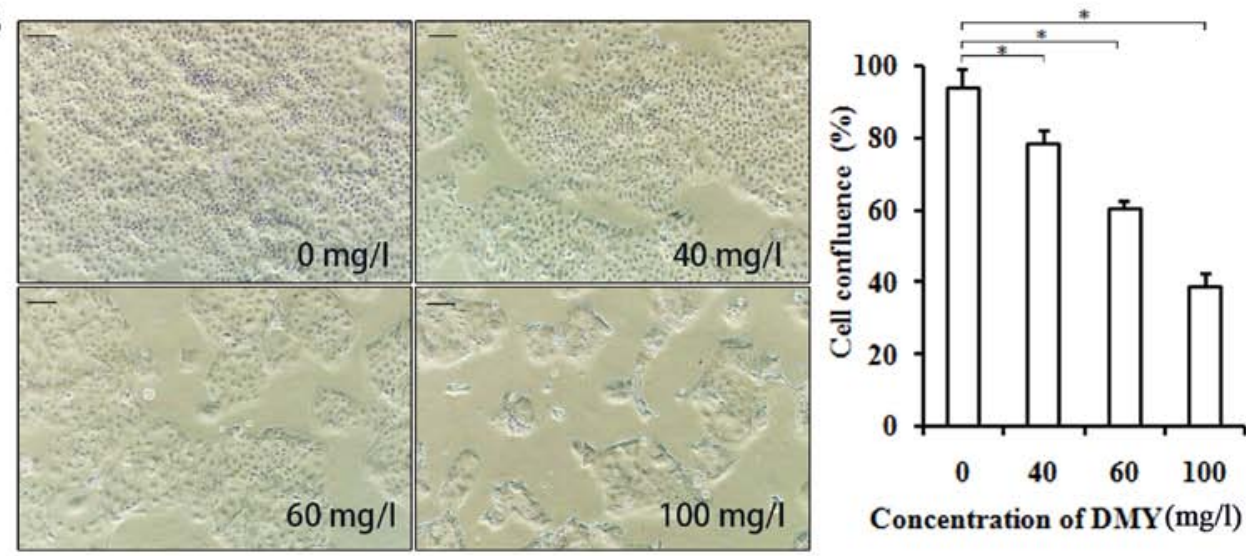

Concentration of DMY $(\mathrm{mg} / \mathrm{l})$

$\mathrm{C}$
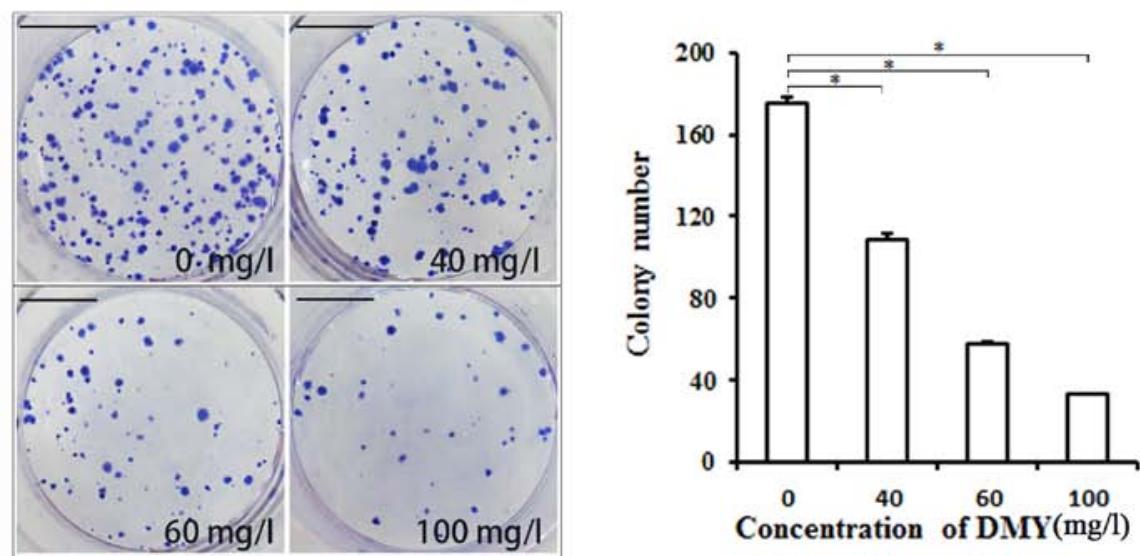

Figure 1. Proliferative ability of JAR cells incubated with different concentrations of DMY for $48 \mathrm{~h}$. (A) Inhibition of JAR cell proliferation with different concentrations of DMY based on MTT assay. (B) Changes in cell confluence observed using an inverted light microscope at x100 magnification. Scale bar, $100 \mu \mathrm{m}$. (C) Colony forming assay performed in 6-well plates with colonies of JAR cells incubated with 0, 40, 60 and $100 \mathrm{mg} / 1 \mathrm{DMY}(0,125,187$ and $312 \mu \mathrm{M}$ ) for $48 \mathrm{~h}$, after which the cells were resuspended and subsequently replated at a density of $400 \mathrm{cells} / \mathrm{well}$. "P<0.05 vs. $0 \mathrm{mg} / 1 \mathrm{DMY}$ group. DMY, dihydromyricetin. Scale bar, $1 \mathrm{~cm}$.

target genes in JAR cells using the $2^{-\Delta \Delta \mathrm{Cq}}$ method (17). The PCR primer sequences are presented in Table I.

Western blotting. Cells were incubated with different concentrations of DMY $(0,40,60$ and $100 \mathrm{mg} / \mathrm{l})$ for $48 \mathrm{~h}$, collected and lysed on ice with RIPA buffer. The cell lysates were centrifuged at $14,000 \mathrm{x}$ g for $10 \mathrm{~min}$ at $4^{\circ} \mathrm{C}$. Subsequently, the supernatant was extracted, and the protein concentration was quantified using a bicinchoninic acid assay kit (Pierce; Thermo Fisher Scientific, Inc.). For SDS-PAGE, $12 \%$ gel was used to separate $30 \mu \mathrm{g}$ protein per sample, which was then transferred onto a polyvinylidene difluoride membrane. Nonfat milk (5\%) was used to block the membranes for $2 \mathrm{~h}$ at room temperature. Next, the membranes were incubated with primary antibodies overnight at $4^{\circ} \mathrm{C}$. The primary antibodies used were against GAPDH $(1: 2,000)$, SMAD3 (1:5,000), SMAD4 (1:5,000), cyclin A1 $(1: 1,000)$ and cyclin D1 $(1: 10,000)$. Subsequently, the membranes were washed in $0.1 \%$ Tween 20 -TBST buffer and incubated with an appropriate secondary antibody $(1: 5,000)$ for $1 \mathrm{~h}$ at room temperature. Immunoreactive bands were detected using an enhanced chemiluminescent substrate (Pierce; Thermo Fisher Scientific, Inc.) and imaged using the Tanon 6100 Chemiluminescent Imaging 


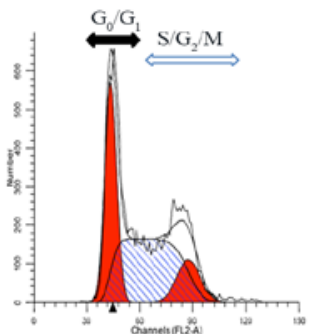

$\operatorname{DMY}(\mathrm{mg} / \mathrm{l}): 0$

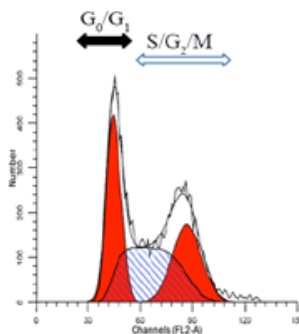

40

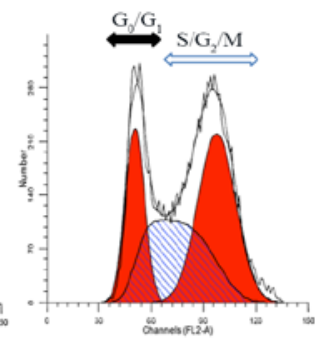

60

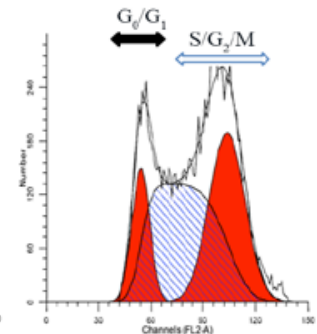

100

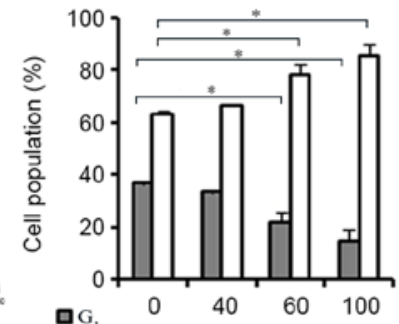

Q $\mathrm{S}_{1} / \mathrm{G}_{2} / \mathrm{M} \quad \mathrm{DMY}(\mathrm{mg} / \mathrm{l})$

Figure 2. Cell cycle analysis. Different concentrations of DMY (60 and $100 \mathrm{mg} / \mathrm{l})$ significantly decreased the number of JAR cells in the $\mathrm{G}_{1}$ phase and increased the number of cells in the $\mathrm{S} / \mathrm{G}_{2} / \mathrm{M}$ phase. ${ }^{*} \mathrm{P}<0.05 \mathrm{vs} .0 \mathrm{mg} / \mathrm{l}$ group. DMY, dihydromyricetin.
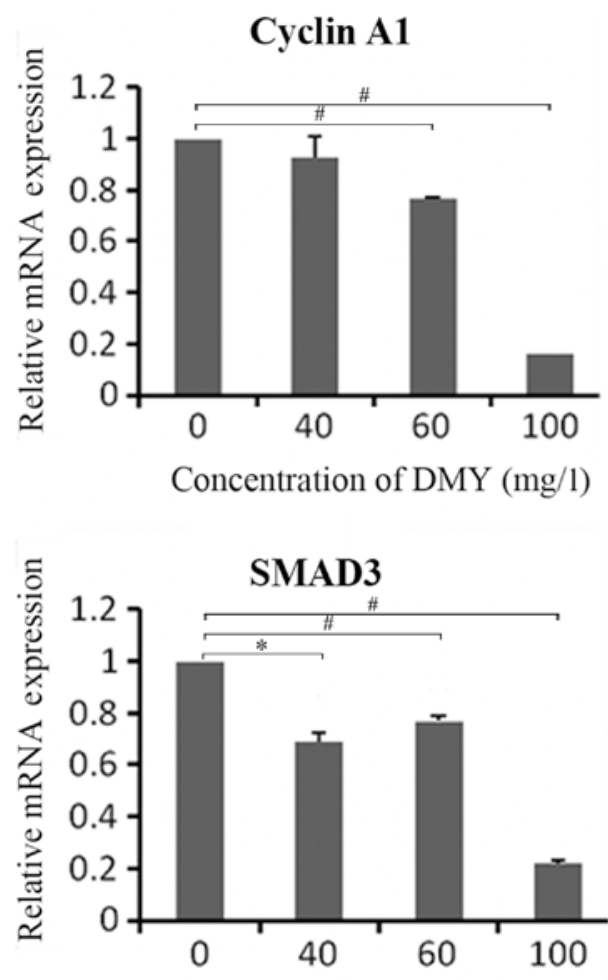

Concentration of DMY $(\mathrm{mg} / \mathrm{l})$
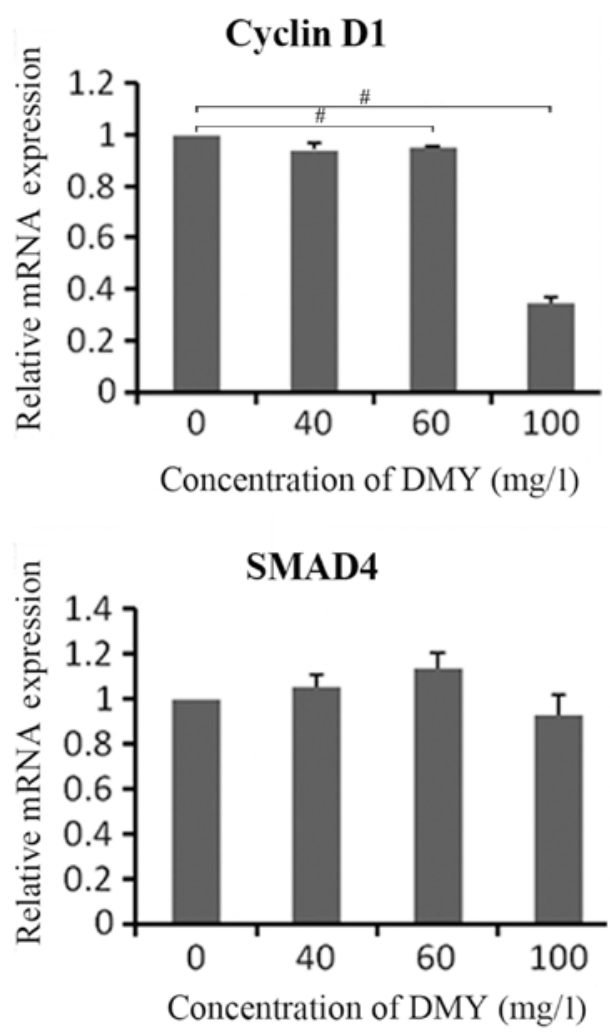

Figure 3. Reverse transcription-quantitative PCR detected mRNA expression in JAR cells incubated with different concentrations of DMY $(0,40,60$ and $100 \mathrm{mg} / \mathrm{l}$ ) for $48 \mathrm{~h}$. The mRNA expression levels of cyclin A1 and D1 decreased with 60 and $100 \mathrm{mg} / \mathrm{l}$ of DMY, though particularly with $100 \mathrm{mg} / \mathrm{l}$ DMY. The mRNA expression level of SMAD3 decreased with 40, 60 and $100 \mathrm{mg} / 1$ DMY. No significant differences were found in the mRNA expression of SMAD4. "P $<0.05$ and ${ }^{*} \mathrm{P}<0.01$ vs. 0 mg/l DMY. DMY, dihydromyricetin.

system (Tanon Science and Technology Co., Ltd.). Band densities were calculated using the Quantity One software version 4.6.2 (Bio-Rad Laboratories, Inc.).

Statistical analysis. All experiments were repeated $\geq 3$ times, unless otherwise indicated. Data were analyzed using SPSS 19.0 (IBM Corp.) and presented as the mean \pm standard deviation. Statistical analysis was performed using one-way ANOVA followed by Tukey's post hoc test. $\mathrm{P}<0.05$ was considered to indicate a statistically significant difference.

\section{Results}

DMY inhibits the proliferation and colony formation of JAR cells. The MTT assay results showed that the proliferation of
JAR cells was significantly inhibited by DMY in a concentration-dependent manner compared with that of the untreated cells $(\mathrm{P}<0.05$; Fig. 1A). Cell confluence decreased significantly with increasing concentrations of DMY, as assessed using an inverted light microscope ( $\mathrm{P}<0.05$; Fig. 1B). The colony forming assay demonstrated that the number of JAR cells clones decreased significantly with increasing concentrations of DMY, compared with the number of untreated cell clones $(\mathrm{P}<0.05$; Fig. $1 \mathrm{C})$.

DMY affects cell cycle distribution in JAR cells. The effects of the different concentrations of DMY were evaluated on the cell cycle distribution in JAR cells using flow cytometry. Compared with the number of untreated cells, increasing concentrations of DMY (60 and $100 \mathrm{mg} / \mathrm{l}$ ) significantly decreased the number 

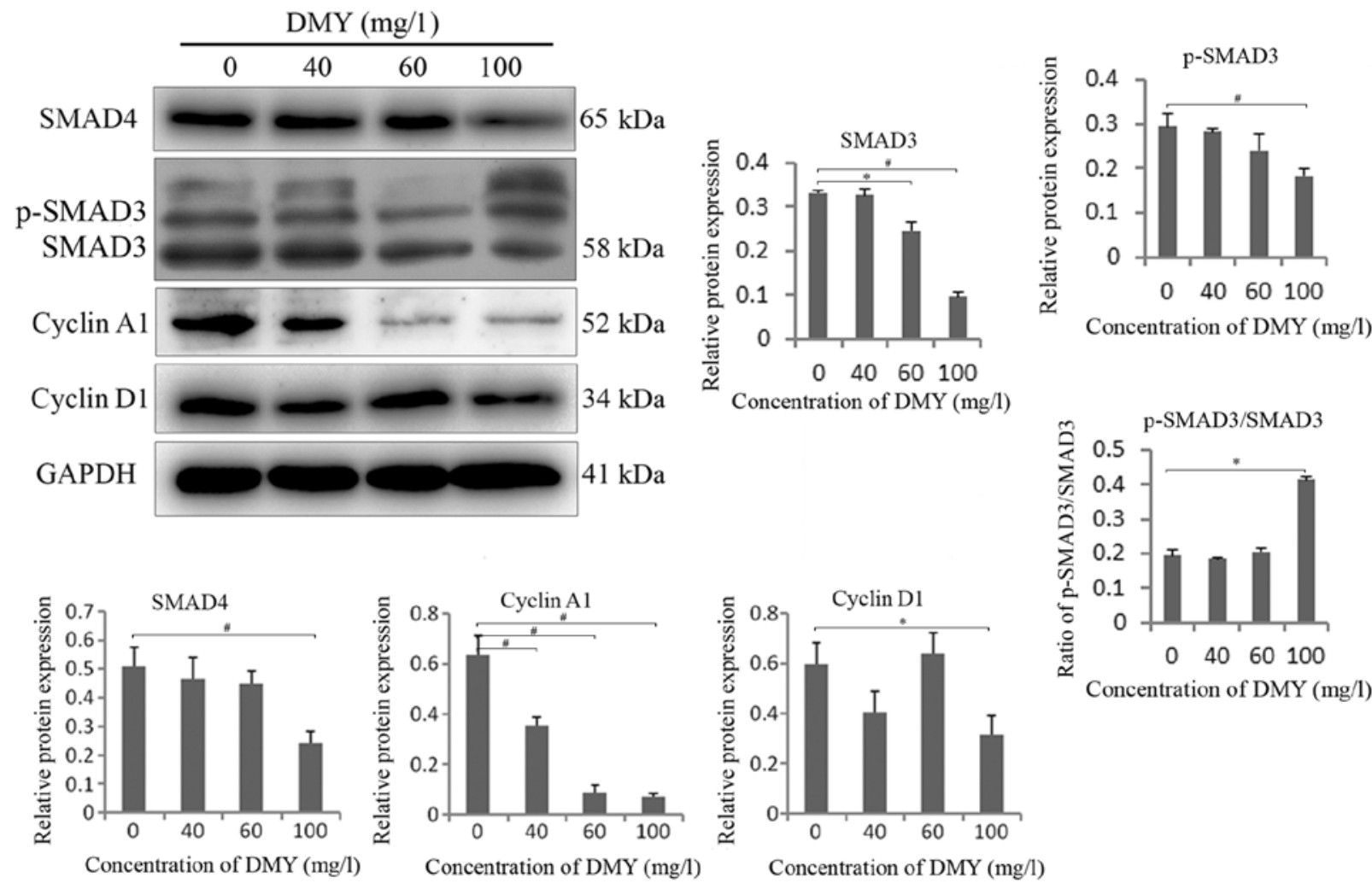

Figure 4. Western blotting. JAR cells were incubated with different concentrations of DMY $(0,40,60$ and $100 \mathrm{mg} / \mathrm{l})$ for $48 \mathrm{~h}$. The protein expression levels of SMAD3, p-SMAD3, SMAD4, cyclin A1 and D1 were decreased in DMY-treated cells compared with the untreated cells. Of note, the ratio of p-SMAD3/SMA3 increased in $100 \mathrm{mg} / 1$ group, we speculate the increase was due to an increase in the bands above p-SMAD 3 instead. ${ }^{*} \mathrm{P}<0.05$ and ${ }^{\#} \mathrm{P}<0.01$ vs. $0 \mathrm{mg} / \mathrm{l}$ DMY. DMY, dihydromyricetin.

of JAR cells in the $\mathrm{G}_{1}$ phase, whilst increasing the number of cells in the $S / G_{2} / M$ phase (Fig. 2).

$D M Y$ regulates the $m R N A$ expression levels of SMAD3, cyclin A1 and cyclin D1 in JAR cells. After a 48-h incubation with different concentrations of DMY, the mRNA expression levels of SMAD3, SMAD4, cyclin A1 and cyclin D1 were quantified using RT-qPCR (Fig. 3). The results indicated that the mRNA expression levels of cyclin A1 and cyclin D1 decreased with 60 and $100 \mathrm{mg} / \mathrm{l} \mathrm{DMY}(\mathrm{P}<0.01)$. The mRNA expression level of SMAD3 decreased with 40, 60 and $100 \mathrm{mg} / \mathrm{l} \mathrm{DMY}(\mathrm{P}<0.05$, $\mathrm{P}<0.01)$. However, no significant differences were observed in the mRNA expression levels of SMAD4 (P>0.05; Fig. 3).

$D M Y$ regulates the protein expression levels of SMAD3, p-SMAD3, SMAD4, cyclin Al and cyclin DI in JAR cells. Western blotting revealed that the protein expression levels of SMAD3, p-SMAD3, SMAD4, cyclin A1 and cyclin D1 were decreased in JAR cells treated with DMY compared with those in the untreated cells particularly in the $100-\mathrm{mg} / \mathrm{l}$ group. The ratio of p-SMAD3/SMA3 increased in $100 \mathrm{mg} / \mathrm{l}$ group $(\mathrm{P}<0.05$; Fig. 4).

\section{Discussion}

In the present study, MTT and colony forming assays were performed to determine the short and long-term inhibitory effects of different concentrations of DMY on the proliferation of JAR cells, respectively. It was found that DMY inhibited the short and long-term proliferation of JAR cells in a concentration-dependent manner. The cell cycle, apoptosis and some signaling pathways are closely associated with cell proliferation. In a previous study, DMY was demonstrated to inhibit cell proliferation by inducing apoptosis in JAR cells (13). In the present study, the inhibitory effect of DMY on the proliferation of JAR cells was explored, based on the cell cycle and TGF- $\beta /$ SMAD signaling pathway (15). The cell cycle was analyzed using flow cytometry, and the results showed that DMY inhibited cell proliferation in association with the regulation of the cell cycle.

Flow cytometry revealed $S / G_{2} / M$ cell cycle arrest in JAR cells treated with DMY. Cyclins are important in the cell cycle control system; cyclins progressively accumulate throughout interphase and abruptly disappear during mitosis during each cell cycle. Escape from cell cycle arrest or from certain nonproliferating states requires the accumulation of cyclins (14). Since the discovery of cyclins in sea urchins by Evans et al (18) in 1983, our understanding of the functions of cyclins in the cell cycle has improved. In mammalian cells, cyclin A accumulates during the late $G_{1}$ phase and is degraded before metaphase (19). Cyclin D was first isolated in a study on parathyroid carcinoma conducted by Motokura et al (20), and it is necessary in the $\mathrm{G}_{1} / \mathrm{S}$ phase of the cell cycle. Cyclin D is generally considered to play a regulatory role by combining with cycle-dependent kinases (CDKs; CDK4 or CDK6) to promote transition from the $\mathrm{G}_{1}$ to the S phase (21). The overexpression of cyclin D1 and CDK4 can cause abnormal proliferation and uncontrolled 
differentiation of cells; these processes are closely associated with the occurrence and development of tumors $(22,23)$. Numerous studies have shown that cyclins are fundamental to the cell cycle, which is important in cell proliferation and differentiation, and is closely associated with the occurrence and development of tumors. For example, alantolactone suggested to inhibit cell proliferation, inducing $\mathrm{G}_{2} / \mathrm{M}$ phase arrest by downregulating cyclin A1 in HepG2 cells (24). A naturally occurring sesquiterpene lactone-Santonin causes SKBR-3 cell cycle arrest at the $\mathrm{G}_{2} / \mathrm{M}$ phase by suppressing the expression of cyclins A and B1 (25). MircoRNA-27a inhibition reportedly triggers $\mathrm{G}_{2} / \mathrm{M}$ arrest in SKOV-3 and OVACAR-3 cells, accompanied by the downregulation of cyclins A and B1 (26). Fucosterol (a phytosterol in marine algae and many other plant species) also triggers $\mathrm{G}_{2} / \mathrm{M}$ cell cycle arrest in A549 and SKLU-1 cells, which is associated with the downregulation of CDK1, cyclin A and cyclin B1, as well as the upregulation of negative regulators of the cell cycle (27). WDR5 induces $S / G_{2} / M$ cell cycle arrest via cyclin $\mathrm{D} 1 \mathrm{in}$ a process that is regulated by $\mathrm{H} 3 \mathrm{~K} 4 \mathrm{me} 3$ (28). In the present study, the results showed that the expression levels of cyclin A1 and cyclin D1 were decreased; thus, DMY may inhibit the proliferation of JAR cells by causing $S / G_{2} / M$ arrest via a decrease in the expression levels of cyclin A1 and D1.

In addition to the association between cyclins and cell proliferation, some studies have shown that the TGF- $\beta / S M A D$ signaling pathway is also associated with cell proliferation $(29,30)$. TGF- $\beta$ activates TGF- $\beta$ receptor (T $\beta R) I$ and T $\beta R I I$, resulting in the phosphorylation of receptor-regulated SMAD2/3, which is associated with the common mediator SMAD4. The SMAD2/3/4 complex is translocated to the nucleus, where it binds to DNA and regulates the transcription of several genes $(31,32)$. Increased mRNA and protein expression levels of SMAD3 and SMAD4 promote cell proliferation, migration and invasion (33). Previous studies have shown that the TGF- $\beta /$ SMAD signaling pathway can regulate the proliferation of choriocarcinoma cells $(15,16)$. In the present study, the mRNA and protein expression levels of SMAD3 and SMAD4 were examined, and the results revealed significantly decreased mRNA and protein expression levels of SMAD3 in cells treated with $100 \mathrm{mg} / 1 \mathrm{DMY}$. The protein expression levels of p-SMAD3 also decreased in $100 \mathrm{mg} / \mathrm{l}$ group. Of note, the ratio of p-SMAD3/SMA3 increased in $100 \mathrm{mg} / \mathrm{l}$ group, and this may be due to an increase in the bands above p-SMAD 3 instead. No significant changes were detected in the mRNA expression level of SMAD4; however, its protein expression was significantly reduced in the $100-\mathrm{mg} / \mathrm{l}$ group. Therefore, it was hypothesized that the treatment might increase protein degradation. Overall, the results indicate that DMY may inhibit the proliferation of JAR cells by decreasing the expression of SMAD3 and SMAD4.

However, one limitation of the present study is that no rescue experiments were performed to determine whether the overexpression of cyclin A1, cyclin D1, SMAD3 and SMAD4 prevents the inhibitory effect of DMY on the proliferation of JAR cells. Nevertheless, the present results provide a foundation for future investigations into more detailed mechanisms.

In summary, the findings of the present study suggest that DMY inhibits the proliferation of human choriocarcinoma JAR cells, potentially by inducing cell cycle arrest via the downregulation of cyclin A1, cyclin D1, SMAD3 and SMAD4. However, the role of other mechanisms, and whether the overexpression of cyclin A1, cyclin D1, SMAD3 and SMAD4 prevents the inhibitory effect of DMY on the proliferation of JAR cells need further clarification. Future studies on DMY will aid in developing it as a potential novel drug for the treatment of choriocarcinoma.

\section{Acknowledgements}

Not applicable.

\section{Funding}

The present study was supported by the Key Subjects in Universities and Colleges of Hebei Province of China [Pathology and Pathophysiology; grant no. JiJiaoGao (2013) 4], the Excellent Innovation Talent Support Plan of Hebei Education Department (grant no. SLRC2017018), and the Project in Hebei Province Department of Population and Family Planning Commission (grant no. 2013-A13).

\section{Availability of data and materials}

The datasets used and/or analyzed during the current study are available from the corresponding author on reasonable request.

\section{Authors' contributions}

YZZ designed the study, performed the experiments, analyzed and interpreted the data, and prepared the first draft of the manuscript. YJL, QX, DYS and XRL contributed to the design of the study, data analysis and revision of the manuscript. XJL performed the experiments. YHL developed the concept of the study and revised the manuscript. All authors read and approved the final manuscript.

\section{Ethics approval and consent to participate}

Not applicable.

\section{Patient consent for publication}

Not applicable.

\section{Competing interests}

The authors declare that they have no competing interests.

\section{References}

1. Pires LV, Yi Y, Cheng JC, Pizzolato LS, Cordero E, Leung PCK and Brum IS: Lapatinib inhibits amphiregulin-induced BeWo choriocarcinoma cell proliferation by reducing ERK1/2 and AKT signaling pathways. Anticancer Res 39: 2377-2383, 2019.

2. Yu S, Wu C, Tan Q and Liu H: Long noncoding RNA H19 promotes chemotherapy resistance in choriocarcinoma cells. J Cell Biochem 120: 15131-15144, 2019.

3. Pearce H, Edwards DC, Levy JA, McGreen BH, Mackovick L, Brennan M, McHugh M, Mapow B, Schanne FJ and Belkoff L: Acute pulmonary hemorrhage associated with metastatic testicular choriocarcinoma in a 46-year-old incarcerated male. Urol Ann 11: 109-112, 2019. 
4. Breitbach GP, Sklavounos P, Veith C, Costa SD, Kuhn W, Solomayer EF, Juhasz-Boess I and Tempfer C: Oral etoposide for metastatic choriocarcinoma: A case report and review of guidelines. Arch Gynecol Obstet 299: 1115-1119, 2019.

5. Wu C, Yu S, Tan Q, Guo P and Liu H: Role of AhR in regulating cancer stem cell-like characteristics in choriocarcinoma. Cell Cycle 17: 2309-2320, 2018.

6. Li H, Li Q, Liu Z, Yang K, Chen Z, Cheng Q and Wu L: The versatile effects of dihydromyricetin in health. Evid Based Complement Alternat Med 2017: 1053617, 2017.

7. Jiang L, Zhang Q, Ren H, Ma S, Lu C, Liu B, Liu J, Liang J, Li M and Zhu R: Dihydromyricetin enhances the chemo-sensitivity of nedaplatin via regulation of the $\mathrm{p} 53 / \mathrm{Bcl}-2$ pathway in hepatocellular carcinoma cells. PLoS One 10: e0124994, 2015.

8. Wong IL, Wang BC, Yuan J, Duan LX, Liu Z, Liu T, Li XM, $\mathrm{Hu} \mathrm{X}$, Zhang XY, Jiang T, et al: Potent and nontoxic chemosensitizer of P-glycoprotein-mediated multidrug resistance in cancer: Synthesis and evaluation of methylated epigallocatechin, gallocatechin, and dihydromyricetin derivatives. J Med Chem 58: 4529-4549, 2015

9. Kao SJ, Lee WJ, Chang JH, Chow JM, Chung CL, Hung WY and Chien MH: Suppression of reactive oxygen species-mediated ERK and JNK activation sensitizes dihydromyricetin-induced mitochondrial apoptosis in human non-small cell lung cancer. Environ Toxicol 32: 1426-1438, 2017.

10. Zhou DZ, Sun HY, Yue JQ, Peng Y, Chen YM and Zhong ZJ: Dihydromyricetin induces apoptosis and cytoprotective autophagy through ROS-NF- $\kappa \mathrm{B}$ signalling in human melanoma cells. Free Radic Res 51: 517-528, 2017.

11. Huang X, Lian T, Guan X, Liu B, Hao S, Zhang J, Bao S, Tan $X$ and Zhu R: Dihydromyricetin reduces TGF- $\beta$ via P53 activation-dependent mechanism in hepatocellular carcinoma HepG2 cells. Protein Pept Lett 24: 419-424, 2017.

12. Zhang QY, Li R, Zeng GF, Liu B, Liu J, Shu Y, Liu ZK, Qiu ZD, Wang DJ, Miao HL, et al: Dihydromyricetin inhibits migration and invasion of hepatoma cells through regulation of MMP-9 expression. World J Gastroenterol 20: 10082-10093, 2014.

13. Zuo Y, Xu Q, Lu Y, Sun D, Wang K, Lei Y, Liang X and Li Y: Dihydromyricetin induces apoptosis in a human choriocarcinoma cell line. Oncol Lett 16: 4229-4234, 2018

14. Alberts B, Bray D, Hopkin K, Johnson A, Lewis J, Raff M, Roberts K and Walter P: Essential cell biology. Fourth edition. Garland Science, Taylor \& Francis Group, LLC, USA, 2014.

15. Li Y, Xu Q, Zhang Z, Liu S, Shi C and Tan Y: The impact of TGF- $\beta 1$ on the mRNA expression of T $\beta R$ I, T $\beta$ R II, Smad 4 and the invasiveness of the JEG-3 placental choriocarcinoma cell line. Oncol Lett 4: 1344-1348, 2012.

16. Tan Y, Xu Q, Li Y, Mao X and Zhang K: Crosstalk between the p38 and TGF- $\beta$ signaling pathways through T $\beta$ RI, T $\beta$ RII and Smad3 expression in plancental choriocarcinoma JEG-3 cells. Oncol Lett 8: 1307-1311, 2014

17. Giulietti A, Overbergh L, Valckx D, Decallonne B, Bouillon R and Mathieu C: An overview of real-time quantitative PCR: Applications to quantify cytokine gene expression. Methods 25: 386-401, 2001

18. Evans T, Rosenthal ET, Youngblom J, Distel D and Hunt T: Cyclin: A protein specified by maternal mRNA in sea urchin eggs that is destroyed at each cleavage division. Cell 33: 389-396, 1983.

19. Fung TK and Poon RY: A roller coaster ride with the mitotic cyclins. Semin Cell Dev Biol 16: 335-342, 2005.
20. Motokura T, Bloom T, Kim HG, Jüppner H, Ruderman JV, Kronenberg HM and Arnold A: A novel cyclin encoded by a bcl1-linked candidate oncogene. Nature 350: 512-515, 1991.

21. Masclef L, Dehennaut V, Mortuaire M, Schulz C, Leturcq M, Lefebvre T and Vercoutter-Edouart AS: Cyclin D1 stability is partly controlled by O-GlcNAcylation. Front Endocrinol (Lausanne) 10: 106, 2019.

22. Yan KX, Liu BC, Shi XL, You BR and Xu M: Role of cyclinD1 and CDK4 in the carcinogenesis induced by silica. Biomed Environ Sci 18: 286-296, 2005

23. Hsu CC, Chen CH, Hsu TI, Hung JJ, Ko JL, Zhang B, Lee YC, Chen HK, Chang WC and Lin DY: The 58-kda microspherule protein (MSP58) represses human telomerase reverse transcriptase (hTERT) gene expression and cell proliferation by interacting with telomerase transcriptional element-interacting factor (TEIF). Biochim Biophys Acta 1843: 565-579, 2014.

24. Kang X, Wang H, Li Y, Xiao Y, Zhao L, Zhang T, Zhou S, Zhou X, Li Y, Shou Z, et al: Alantolactone induces apoptosis through ROS-mediated AKT pathway and inhibition of PINK1-mediated mitophagy in human HepG2 cells. Artif Cells Nanomed Biotechnol 47: 1961-1970, 2019.

25. Wu Z, Wang C, Huang M, Tao Z, Yan W and Du Y: Naturally occurring sesquiterpene lactone-santonin, exerts anticancer effects in multi-drug resistant breast cancer cells by inducing mitochondrial mediated apoptosis, caspase activation, cell cycle arrest, and by targeting Ras/Raf/MEK/ERK signaling pathway. Med Sci Monit 25: 3676-3682, 2019.

26. Si L, Jia Y, Lin R, Jian W, Yu Q and Yang S: MicroRNA-27a regulates the proliferation, chemosensitivity and invasion of human ovarian cancer cell lines by targeting Cullin 5. Arch Biochem Biophys 668: 9-15, 2019.

27. Mao Z, Shen X, Dong P, Liu G, Pan S, Sun X, Hu H, Pan L and Huang J: Fucosterol exerts antiproliferative effects on human lung cancer cells by inducing apoptosis, cell cycle arrest and targeting of Raf/MEK/ERK signalling pathway. Phytomedicine 61: $152809,2019$.

28. Sun W, Guo F and Liu M: Up-regulated WDR5 promotes gastric cancer formation by induced cyclin D1 expression. J Cell Biochem 119: 3304-3316, 2018.

29. Zhou J, Zhang C, Zhou B and Jiang D: miR-183 modulated cell proliferation and apoptosis in ovarian cancer through the TGF- $\beta /$ Smad4 signaling pathway. Int J Mol Med 43: 1734-1746, 2019.

30. Sun L, Dong Z, Gu H, Guo Z and Yu Z: TINAGL1 promotes hepatocellular carcinogenesis through the activation of TGF- $\beta$ signaling-medicated VEGF expression. Cancer Manag Res 11: 767-775, 2019.

31. Shi Y and Massagué J: Mechanisms of TGF-beta signaling from cell membrane to the nucleus. Cell 113: 685-700, 2003.

32. Zuo Y, Fu Z, Hu Y, Li Y, Xu Q, Sun D and Tan Y: Effects of transforming growth factor- $\beta 1$ on the proliferation and invasion of the HTR-8/SVneo cell line. Oncol Lett 8: 2187-2192, 2014.

33. Li Q, Liu X and Zhao C: Smad4 gene silencing enhances the chemosensitivity of human lymphoma cells to adriamycin via inhibition of the activation of transforming growth factor $\beta$ signaling pathway. J Cell Biochem 120: 15098-15105, 2019.

This work is licensed under a Creative Commons Attribution-NonCommercial-NoDerivatives 4.0 International (CC BY-NC-ND 4.0) License. 